\title{
NEW MEDIA - CHALLENGE FOR THE RULERS
}

\author{
by Marta Dorenda
}

\section{INTRODUCTION}

Political life in western democracies, even beyond the periods of subsequent elections, resembles permanent electoral campaign. All the actions of politicians and public relations of professionals are calculated to maintain supporters, attract hesitant citizens and persuade opponents. There is a common perception of media as a channel serving politicians, supported by spin doctors, to submit messages, aiming at achievement of political success. Analysis of changes in terms of communication and political marketing requires redefinition of classical categories operated by political marketing and communication, namely the notions of sender, message and receiver. While reformulating these categories, it is necessary to also analyze new tools and devices used by domains mentioned above. Presentation and explanation of their new content, definitions and relations between them leads to the conclusions concerning new role of media in the world dominated by high technologies. 


\section{INFORMATION IS NOT ENOUGH}

In his work, The Rise of the Network Society, Manuel Castells claims that we live in the world ruled by informationism. ${ }^{1}$ Mirosława Marody translates this term as "a system oriented towards technological development, accumulation of knowledge and high level of complexity of transformed information. In such conditions, the dominating form of integration of social space are global networks, where symbols circulate constantly, determinating the circulation of capital, power and knowledge."2 Integration of social space in a form of global networks means that a common space for the users is defined, being a synthesis of multiplicity of the elements of contemporary world. Existence of global networks allows to transfer infinite amount of messages amongst various receivers. Consequently, this means a radical change of communication culture on a large scale. ${ }^{3}$

Owing to the networks, it is possible to employ already existing symbols - seemingly simple slogans, transferring particular knowledge. The ability to create such symbols and supply them with desired meaning, which evokes specific associations, may, in the era of informationism, signify success in terms of marketing. The importance of efficient diffusion of symbols is often greater than the meaning of content they indicate. Castells perceives this phenomenon in a context of "technological revolution": "Together with the evolution, concerning both the Internet and society, the role of politics in our lives changes significantly. What constitutes a source of power nowadays, is the possibility to create and spread cultural codes."4 It occurs mainly by means of networks such as the Internet, and, due to a great number of its users, the information spread in one point is immediately forwarded by multitude of recipients. To perform this successfully, a message needs to be reduced to the simplest form a symbol, which is only one of the many other elements enabling a sender to reach recipients and ensure proper reception of the information.

1 M. Castells, The rise of the network society, Wiley-Blackwell, San Francisco 2000, p. 6.

2 E. Bendyk, Sieć z dużymi dziurami, „Polityka”, No. 47 (2630), p. 96.

3 E. Bendyk, Gadu-Gadu, czyli natychmiast w sieci, „Polityka”, No. 39(2622), p. 18

${ }^{4}$ M. Castells, Galaktyka Internetu. Refleksje nad Internetem, biznesem i społeczeństwem, Dom Wydawniczy Rebis, Poznań 2003, p. 186. 


\section{DIGITISED SOCIETIES}

Analysing the significance of networks in social and political reality, Marody points out other factors influencing persuasive efficiency of the message. She mentions that "functioning of technologically developed civilization not only requires enormous supplies of knowledge, but also the ability of its reproduction within the society (...). The society itself is a fragile formation, existing as long as its members maintain a common idea of continuity and identity. Neither the greatest supplies of knowledge nor technological sophistication guarantee sufficiency of this common idea to preserve the society, particularly in the situation of its radical structural changes." 5 However, the Internet without a doubt serves as a perfect example of global network, playing important political role. During the analysis of its influence on exercising power, one cannot act according to simple schemes. Amongst the actors of political system, particular kind of communication, based on specific cultural codes, occurs. Their integrating power lasts as long as they stay the same for all social groups. This condition also needs to be fulfilled if communication between a sender (in this case - a politician) and a receiver (a citizen) is supposed to be efficient and bring desired results.

Nowadays, networks are employed in all domains of human activity, and for the flexibility of links between their elements, their usage ensures higher level of efficiency than hierarchical bureaucracy. Edwin Bendyk opposes this efficiency to ambivalent aspect of networks as being "a way of subjecting the world to a man," developing according to the logic "inevitably leading to domination of technology." As a result, "a man becomes an element of the system, a single point in total network, growing faster and faster, with the aim of final extermination of modern civilization." 6 This catastrophic point of view, considering a man as a passive element of a network, is also recognized by Marody. Nevertheless, she notices a solution of this oppressive situation. Interpreting Castells, she stresses that "auto-exclusion from the network cannot serve as a solution

\footnotetext{
5 E. Bendyk, Sieć z dużymi dziurami..., p. 96.

6 E. Bendyk, Antymatrix. Człowiek w labiryncie sieci, W.A. B., Warszawa 2004, p. 33.
} 
because in modern world those who are not included in it, do not exist. The point is to take the advantage of one's presence in the network."7 Apart from futurological considerations on the influence of rapid development of the Internet on our civilisation, what also should be noticed, is the dynamics and adaptation abilities - the main features of the Web. Its network structure perfectly fits the requirements of politics considered as communication between its actors. It is definitely something more than a useful tool. For the fact that it is being created and transformed by its users, it constantly evolves, accommodating to fluctuating social needs. Ensuring unlimited possibilities, the Internet becomes a preferable means of communication, undergoing permanent improvements.

\section{NEW MEDIA, NEW MESSAGE}

A significant feature of new media is an attempt to reach simultaneously two aims of communication, concerning both individual and collective domain, whereas new media touch rather individual aspect of human activities. ${ }^{8}$ Popularity of new media implicates that contemporary means of communication have adapted to individual behaviors and preferences. The process mentioned above launches a dispute concerning complex social problems, such as relations between individuals themselves, connections within national communities as well as cultural interconnections between nations. ${ }^{9}$

Although an expression "new media" has been in use since 1960s, its definition still causes several problems. The authors of Handbook of New Media make an attempt to construct the definition of new media, inserting information-based theories of communication in proper social contexts, and, subsequently, connecting three groups of elements: artifacts and technical devices; activities, practices and habits, as well as structures

\footnotetext{
7 E. Bendyk, Sieć z dużymi dziurami..., p. 96

8 D. Wolton, Internet et après, Flammarion, Paris 2000, p. 24.

9 Ibidem.
} 
and social organizations based on those devices and practices. ${ }^{10}$ Leah Lievrouw together with Sonia Livingstone noticed, however, that a similar definition may also concern traditional media, whereas its designations are different. ${ }^{11}$ An attempt to define what new media are was also made by Tomasz Goban-Klas, who named them "telematic media", representing the highest level of development of communication technologies. GobanKlas, "enumerating new media, employs this name for the means of communication based on electronics. He claims that new media employ mainly digital devices, using them for coding the signal and transferring information."12 Goban-Klas also stresses that new media use various sorts of technologies serving interactive transmission, storage and retrieving information. A feature that distinguishes them from already known means of communication is decentralization and greater group of people being in control of the information. Neither creation nor choice of messages is the domain of institutions. Existence of new media is also determined by great throughput of transmission channels, enabling the sender to omit the limits of the amount of transferred information, as well as its cost. The most important for the recipients is interactivity of the means of communication - "a recipient may choose, reply, exchange information and be directly connected with its source" and flexibility of their form, content and the way they are used. Denis McQuail created a catalogue of new media features, defining them as technologies based on processors or employing computers. According to McQuail, those media are interconnected. They assure interactions between the users, both private and public, and the low level of regulation exercised on them. ${ }^{13}$

Although this technological description of new media seems to be "sociologically primitive,"14 it is necessary to analyze and understand possible influence of new media on their users and, consequently, on the way

10 D. McQuail, Teoria komunikowania masowego, Wydawnictwa Naukowe PWN, Warszawa 2007, p. 57.

11 L. Lievrouw, S. Livingstone, The Handbook of New Media, Sage, London 2002, p. 168.

12 T. Goban-Klas, Media i komunikowanie masowe: teorie i analizy prasy, radia, telewizji i Internetu, Wydawnictwa Naukowe PWN, Warszawa 1999, p. 24.

13 McQuail, Mass Communication Theory. An Introduction, Sage, London 1994, p. 98.

14 T. Goban-Klas, Media i komunikowanie masowe..., p. 290. 
they are used by senders of messages. "Telematic" media have also changed perception of communication, breaking simple scheme based on figures of a sender, a message and a recipient. Therefore, if we consider culture as a form of communication, we may describe the changes mentioned above as digital cultural revolution.

New mode of information transfer is connected with revolutionary social and cultural changes, leading to the growth and specialization of the recipients' knowledge. Media and new techniques are complementary, as far as theory of communication is concerned, because they refer to a common model of individualized mass society. ${ }^{15}$ What Wolton calls "an area of information" is getting more extensive, whilst "transformation of communication forms causes changes of its content."16 Recipients (or rather customers) are able to make a choice amongst wide variety of messages. They may also react to them or create the information themselves. Media no longer satisfy social need for information, as it is replaced by general strive for automation, organization and structuration of already existing knowledge and creating the new one according to the demand. ${ }^{17}$ Original idea of democratization has surrendered to specialization of information according to target groups of the sender.

\section{UBIQUITOUS NETWORK}

The analysis of phenomenon of new means of communication focuses mainly on the Internet - the medium which launched "revolution that made new society appear." 18 According to Jan Grzenia, „the Internet is the only medium having the features of communication tool, whereas the other media simply transfer messages." Followers of a specific form of technological determinism claim, that revolution in terms of technologies will result in another one - a global structure of societies. Materialist and

15 Ibidem, p. 201

16 R. Tsagarousianou, D. Tambini, C. Bryan, Cyberdemocracy. Technology, cities and civic network, Routledge, London 1998, p. 5.

17 Ibidem, p. 94.

18 Ibidem, p. 17. 
subjective conception of communication, as a tool of information transfer, is supplanted by technological ideology of communication. ${ }^{19}$ Therefore, the first task of the Internet appears: to make media approach their users, not make people and societies act according to the rules of technological models. Wolton, presenting tasks and functions of new media from psychological and social point of view, stresses the fact that on one hand opening mass media for new information should be promoted, whilst on the other hand their omnipotence and omnipresence ought to be limited. Strive for improvements and modernization of communication techniques should be replaced (or at least treated equally) by seeking for cooperation and humanization of relations between citizens. ${ }^{20}$ The aims that the Internet is expected to achieve, however noble and justified, are utopian. The Web is supposed to constitute the medium of new conscience and solidarity, as for development of information society is inseparably connected with the collapse of economic barriers. ${ }^{21}$

As far as political system is concerned, the Internet enables the citizens not only to control official power, but also define their own political environment. Acting in favour of autonomous expression as well as conducing to the development of protest movements, ${ }^{22}$ modern technologies contribute to the realization of democratic ideals, such as establishing political priorities in small communities. Digital networks create the possibility to avoid "plebiscite rituals" connected with the management of those communities and establishment of their own hierarchy of issues. ${ }^{23} \mathrm{~A}$ function of socialization is also completed as the principles are defined both for individuals and a whole community, which forces its member to cooperate. ${ }^{24}$ Improvement in the domain of quality of offered services influences quality of life in the communities - their needs may be precisely examined

19 J. Grzenia, Strona WWW jako forma dialogowa, [in:] Dialog a nowe media, ed. M. Kita, Wydawnictwo Uniwersytetu Śląskiego, Katowice 2004, p. 27.

20 Ibidem, p. 87.

21 Ibidem, p. 91.

22 T. Vedel, Internet et les pratiques politiques, [in:] L'Internet en politique des Etats-Unis à l'Europe, ed. V. Serfaty, Presses Universitaires de Strasbourg, Strasbourg 2002, p. 204.

23 P. Mathias, La cité Internet, Flammarion, Paris 1997, p. 48.

24 Ibidem, p. 52. 
by the devices such as various forms of vote, referendum, opinion polls. That gives the opportunity to solve particular problems emerging from imperfections of democratic system. ${ }^{25}$ The Internet does not create a phenomenon precipitously named "cyberdemocracy", since "cybercitizen" of virtual space does not exist. According to Urszula Jarecka, "the Internet creates specific form of contact which is virtual, but the name 'virtual community' is not suitable as we observe only virtual aspects of real communities' existence."26 Network communities are rather a part of new "communicational universe,"27 adherence to which is voluntary and signifies unlimited freedom, regardless of its positive and negative aspects.

Manuel Castells undermines the idea presented above, considering the Internet as "global electronic agora, noisy with the turmoil of social dissatisfaction." ${ }^{28}$ However, according to the theory of Karl Deutsch, circulation of information is necessary for functioning of each government and apparently only new media are able to cope with the amount of information circulating amongst several political actors. New media also assure differentiation of knowledge sources owing to their decentralization. Virtual network may also act in favour of improving a system of information transfer, typical for democratic systems. It serves as a significant tool of political mobilization, integrating several social groups, diminishing costs of coordination and solving the problem of territorial dispersion and serving as a method of publicity. New technologies contribute to measuring political preferences of citizens, which positively influences electoral participation level in liberal democracies. Moreover, the Internet constitutes a significant channel of communication between politicians and the subjects of their power ${ }^{29}$ Owing to its universality, scope and influence, the Internet serves for transparency of public life, being one of fundamen-

25 R. Tsagarousianou, D. Tambini, C. Bryan, Cyberdemocracy. Technology, cities and civic network, Routledge, London 1998, p. 8.

26 U. Jarecka, Wirtualne więzi w globalizujacym się świecie, [in:] Kultura w czasach globalizacji, ed. M. Jacyno, A. Jawłowska, M. Kempny, Wydawnictwo Instytutu Filozofii i Socjologii PAN, Warszawa 2004, p. 271.

27 Ibidem, p. 54.

28 M. Castells, Galaktyka Internetu, Rebis, Poznań 2003, p. 158.

29 T. Vedel, Internet et les pratiques politiques..., pp. 192-196. 
tal values in contemporary democratic systems..$^{30}$ Above all, the Web ensures a device of verification of respect for the principles of democracy, social contract and universal equality before the law. It refers to the powers of civil society to exercise control over the actors of political system and to the right of every citizen to possess their own opinion concerning political activities of their representatives. The Internet ensures also wider access to the information as well as public data by its efficient and inexpensive devices of storage and distribution of information. Owing to this medium, the politicians may become acquainted with postulates and opinions of their electors in simple, rapid and precise way.

Owing to transgression of geographic, social and cultural borders, as well as, in specific conditions, unlimited freedom, efficient stimulation of public debate becomes possible. Functions of the Internet in terms of political system also concern the aspect of electoral campaigns. This medium has become a significant issue of the campaigns, enabling political parties or candidates to control the message they send and to address it directly to precisely defined groups of receivers, as well as to create innovative, interactive forms of reaching them. ${ }^{31}$ This, consequently, means that political fight loses timeframes as it takes place constantly, in space occupied by all political actors. ${ }^{32}$ This phenomenon may be considered as favourable also for themselves. Fulfilling basic rule of free market - taking decisions in conditions of unlimited information is no longer utopian, although, as Marc Clément notices, "access to reliable knowledge through the medium of the Internet requires reliable formation of individuals," ${ }^{33}$ what signifies the necessity of diligent filtration of provided content.

30 R. Tsagarousianou, D. Tambini, C. Bryan, Cyberdemocracy..., p. 6.

31 Ibidem, pp. 186-193.

32 S. Magniant, B. Villalba, Mobilisations politiques locales et nouvelles technologies de l'information et de la communication, [in :] L'Internet en politique des Etats-Unis à l'Europe..., p. 144.

${ }^{33}$ M. Clément, Internet: l'avenir radieux!, [in :] L'Internet en politique des Etats-Unis à l'Europe..., p. 273. 
According to Marek Hetmański, "majority of the Internet analysis stresses technical aspect of that medium." ${ }^{34}$ The tasks of new media presented in this context may be divided into three categories: functions of information, referring to the essential principles as far as functioning of modern societies is concerned; functions of expression, satisfying the needs of unconstrained manifest of opinions; functions of communication, indispensable to understand vast content being transferred rapidly. The functions enumerated above may be reduced to efficient operations on extremely vast amounts of data. They are created and modified, stored and deleted with no spatial or temporal limits. Global networks enable its users to „exchange and manipulate signs and symbols: text, image, sound, any type of data." ${ }^{35}$ It gives the individuals the possibility of unconstrained shaping their competences, aims and relationships. The Internet "undermines the system of centralized and available only to a limited group of professionals means of communication." ${ }^{36}$ Unlimited access to databases ensures authentic progress - not only does it diminish the time needed to obtain the information, but also enables the user to seize it. The Internet "is treated as perfect infrastructure of communication, multiplying the effects of all already used devices." ${ }^{37}$ Moreover, new technologies satisfy the need for action, realized in terms of knowledge, documentation and experience, as well as development of the abilities of creation, imagination, looking for new style and forms of expression, which contribute to formation of contemporary culture. Both feature and a function of the Internet ensure its users equal access to passive reception of information and means of expression. There exists no a priori established hierarchy which is considered a symptom of emerging of new network society, free and

34 M. Hetmański, Internet jako środek tworzenia i komunikowania wiedzy, [in:] Internet. Fenomen społeczeństwa informacyjnego, ed. T. Zasępa, Edycja Św. Pawła, Częstochowa 2001, p. 67.

35 J.M. Besnier, Laïciser Internet. Les TIC et le temps, „Raison publique”, No. 2 (2004), p. 36.

36 P. Mancini, D. Swanson, Politics, Media and Modern Democracy: An International Study of Innovations in Electoral Campaigning and Their Consequences, Greenwood, Westport 1996, p. 28.

37 R. Tsagarousianou, D. Tambini, C. Bryan, Cyberdemocracy..., p. 5. 
demonstrating solidarity, contributing to rise of new culture. ${ }^{38}$ The situation described above may be compared to a market, where everyone may offer their goods, being a subject of no control. It is optimistically assumed that sellers are honest, while customers - rational.

\section{INFORMATION POLICY IN CYBERSPACE}

Despite unquestionable connections with politics, the Internet may not replace properly the functioning of political system. However, it may contribute to the fulfillment of one of its basic functions, named by Castells "information policy" 39 These are the media and their principles that have significant influence on governors' reception of public opinion. Means of communication may stimulate citizens to express their opinions, they may also shape political preferences, whilst the Internet offers the possibility of their unconstrained manifestation. As far as particular example of political blogs is concerned, the Web enables the users to react directly to published information as well as to approach a sender, avoiding traditional channels of communication. Henry Jenkins stresses interactivity of new means of communication, announcing "rise of social networks and mobile media”, starting "dialogue with mass media, creation of network communities, learning to think, and transforming reality in new ways." 40 The "new way" mentioned by Jenkins signifies a culture of participation a recipient becomes more and more visible.

Neil Postman in his book Technopol presents pessimistic visions of the world where culture surrenders to technology, ${ }^{41}$ whereas nowadays we can observe the symbiosis of those two domains. A phenomenon that may be called "technoculture, though strongly technologised culture, strongly influenced by the Internet" 42 emerges. Development of the Web did not

38 D. Wolton, Internet et après..., p. 90.

39 M. Castells, The Power of Identity, Blackwell Publishing, Malden 2004.

40 H. Jenkins, Kultura konwergencji. Zderzenie starych i nowych mediów, Wydawnictwa Akademickie i Profesjonalne, Warszawa 2007, p. 7.

41 N. Postman, Technopol: triumf techniki nad kultura, „Muza”, Warszawa 2004.

42 Z. Miłoszewski, Technokultura, „Newsweek” 2008, No. 6, p. 88. 
suppress generally defined culture or social life, but rather started the rise of new fields and symptoms of its functioning, such as new media. A specificity of Web 2.0 phenomenon is the fact that "new media are (...) currently redefined by various groups of consumers. (...) New ways of using the Internet for various purposes are internalised. (...) Moreover, those changes take place on a global scale." 43 Every user of the Internet may create their own space and decide with whom they wish to share it. As far as political marketing is concerned, this phenomenon creates unlimited possibilities of self-creation for politicians, whilst a recipient obtains a chance to exercise direct influence on governors. Global network, owing to its transformation, offers significant tools of image creation and maintenance. An idea of Web 2.0 also includes blogosphere. Blogs are not definitely new devices, however recently, together with the development of thematic blogs and improvements they offer, significant growth of their popularity has been noticed. ${ }^{44}$

As for the importance of the Internet, as means of communication, it is evident that politicians and political parties benefit from its development. Bendyk stresses that "the power propelling this world is innovativity and creativity, realized both in non-market-related social space and in conditions of free, global market. A common feature is the fact that the conditions of innovativity and creativity are social relations and the ability to communicate." 45 As it has already been mentioned, communication constitutes the basis of efficiently performed politics. Bendyk considers communication not as a simple transfer of messages, even if a sender expects certain feedback, but as creating conditions in which such feedback would be addressed immediately and directly to the sender. The Web becomes a significant tool, used for sharing information, gaining supporters, convincing the opponents, broadening scope of power as well as repulsing political attacks. According to Castells "cyberspace becomes

43 H. Jenkins, Kultura konwergencji..., p. 8.

44 . Domaszewicz, Czy Web 2.0 to rewolucja w Internecie?, „Gazeta Wyborcza” No. 55 , p. 30 .

45 E. Bendyk, Kooperacja zamiast korporacji, „Niezbędnik inteligenta” No. 25 (2559), p. 37. 
a field of rivalry," 46 which results in transformation of rules in political game. In this rivalry, politicians no longer are sole actors - the audience of the game becomes its part. When the Web is one of the strongest factors that influence the consumers' decisions, the game is all about giving them the chance to confront the powerful machine of marketing. This rivalry, considered in categories of political marketing, gains new element a necessity of creating "personal" contact of an author of a message (though the politician) with the recipient - an elector.

\section{SUMMARY}

In classical concept of political marketing and political communication it is the recipient who may be considered a central figure. All the actions performed by politicians were addressed to their electors, they were the objects of persuasion or manipulation, these were the recipients who internalized the knowledge offered by specially prepared actors of political system. Appearance and growing importance of new media contributed to redefinition of the situation mentioned above. Interpretation of political communication exclusively as "a servant" of political marketing, whilst political marketing itself as a reprehensible phenomenon placed somewhere in between sophistry and primitive advertisement, was proven incomplete. The influence and significance of communication for political systems and, therefore, societies, was noticed. Already defined role of the recipient is disturbed and the border between them and senders of messages is now unclear. They may both play roles simultaneously - the audience has become a sort of "a producer" of the message. Such a situation induces politicians to strive for new means of approaching their electors, accustomed to sophisticated methods of gaining their attention, though more and more demanding.

46 M. Castells, Galaktyka Internetu..., p. 157. 